\title{
Development of Web-Based Science Learning Module in Improving the Students' Understanding of Eco-Literacy
}

\author{
Amalia Firdausi, *Fitria Eka Wulandari \\ Natural Science Education Department, Universitas Muhammadiyah Sidoarjo. Jl. Mojopahit No. 666 \\ B, Sidowayah, Sidoarjo, 61215, Indonesia \\ *Corresponding Author e-mail: fitriaekawulandari@umsida.ac.id
}

Received: March 2021; Revised: September 2021; Published: November 2021

\begin{abstract}
This study aims to determine the feasibility of the module in improving students' understanding of eco-literacy. This research is development research using the $4 \mathrm{D}$ development model with ten students as research participants. The learning module developed is validated by two competent validators from internal and external campuses. The feasibility of the module includes the validity and reliability of the module as measured by the validation questionnaire sheet. The validation results show that the module obtained an average score of 3.66 (very valid category), with the reliability score of 0.83 (real category). The research data were analyzed descriptively and quantitatively. Students' understanding was measured on the competency test in the module on the pretest and posttest after giving the treatment. The results of the module trial calculated using the $\mathrm{N}$-gain formula indicate that the effectiveness was under the high category with a score of 0.703 with an average pretest and posttest values of 43.7 and 83.49 , respectively. Based on the study results, it can be concluded that the webbased science learning module developed is valid, reliable, and effective in improving students' understanding of eco-literacy.
\end{abstract}

Keywords: eco-literacy; web-based module; students' understanding

How to Cite: Firdausi, A., \& Wulandari, F. E. (2021). Development of Web-Based Science Learning Module in Improving the Students' Understanding of Eco-Literacy. Jurnal Penelitian Dan Pengkajian Ilmu Pendidikan: E-Saintika, 5(3), 241-252. https://doi.org/10.36312/esaintika.v5i3.426

https:// doi.org/10.36312/esaintika.v5i3.426

Copyright@ 2021, Firdausi \& Wulandari This is an open-access article under the CC-BY-SA License.

\section{INTRODUCTION}

The environment is a combination of interactions between biotic and abiotic components in which its existence depends on human behavior in maintaining the environment. The balance of these two components positively affected the survival of human beings and organisms. In contrast, the imbalance of biotic and abiotic components can damage the environment, negatively affecting the living beings inside it. Some of the inevitable impacts of environmental damage are the emergence of natural disasters, the extinction of a species, and the abnormality of the ecosystem (Syukron, 2019). The bad impact occurs not because the earth is older but because of human behavior that utilizes nature continuously without preserving it (Mardliyah et al., 2018). Thus, a lot of environmental damage happened due to the activities of humans, the living being that has a lot of interaction with the environment and other organisms (Haris \& Purnomo, 2016). 
Environmental damage also happens because of human's greed for natural resources (Iswari \& Utomo, 2017). To fulfill the need, humans tend to do activities that harm the environment, such as using the bomb to catch fish, to fulfill residences area by cutting down forest and others. This condition will continue to occur as the increasing number of human populations always utilize and exploit nature without paying attention to its condition and preservation (Nurfajriani et al., 2018). According to IPCC (Intergovernmental on Climate Change) and G-8 Group (developed country) research with 20 big economic countries, environmental damage, the rise of global temperature, and depletion of natural resources occurs due to human actions. Humans overexploit nature irresponsibility (Supriatna, 2016). This condition has become the responsibility of human beings as the subject which did not preserve the use of the environment (El-Mallah et al., 2019). The responsibility of the environment is attached to the government and people (McCarthy \& Burke, 2017). A sense of responsibility can appear if one is aware of a condition of an environment. Environmental awareness will positively influence the insight, action, and concern towards the importance of environmental preservation efforts (Kukkonen et al., 2018). Environmental awareness will affect an individual mindset in responding to the condition of the environment in the present and the future or called by eco-literacy education (Itafarida et al., 2019).

Eco-literacy education can be used to raise awareness in people of environmental conditions. Eco-literacy has an essential effect on awareness of the environment (McBride et al., 2013). With eco-literacy, one can expand their insight around the environment and the impact caused by their actions towards the environment. This enables someone to be more careful in preserving and acting towards the environment. Someone who understands the concept of ecology would apply their understanding in daily activities (Rusmawan, 2017). Research by Sigit et al. (2021) shows that knowledge about the environment or eco-literacy has a positive relationship with the concern of the environment. The introduction of eco-literacy from an early age can create individuals aware of the environment (Desfandi et al., 2017). Early introduction is conducted so that children can apply the understanding they received by getting used in their interaction with the environment (Wahyudi et al., 2020). Aside from that, early introduction to eco-literacy is the best way to create a generation of environmental literacy, since in this age, cognitive, affective, and psychomotor development is increasing rapidly (Siregar et al., 2020).

The introduction of eco-literacy can be done through school learning, which has become one of the available efforts to know and teach the concept since early years. Eco-literacy learning becomes one of the fundamental things in influencing the students' awareness of natural conservation (Yannis \& Gillian, 2017). According to Williams (2017), eco-literacy learning needs to be taught and applied to the curriculum at every level of education. The same opinion was also stated by Ikhsan et al. (2019) that eco-literacy needs to be taught and applied in the learning process at all levels of education. This implementation can be done by adding eco-literacy to the media used for learning. It is in line with the statement of Sigit et al (2019), that the implementation of eco-literacy can be done by using modules as learning media that have been combined with eco-literacy.

Learning media becomes a component of learning. It is created to help achieve material in learning (Fathiyati \& Utami, 2016). A module is systematically composed of information of learning materials, methods to evaluation that can be used in the 
learning together with the teacher and individually (Solikin \& Amalia, 2019). Technology advances enable module creation in digital documents (Solikin, 2018). Aside from that, creating a digital module can be equipped with the web to give broader information and phenomenon. With the web, various types of information are text, pictures, video, or other information used in web-integrated learning (Fatah et al., 2021). Information gathered directly through the web enables students to learn widely either with the teachers or independently. The research by Asi and Anggraeni (2018) shows that web-based learning is more preferable by the students, aside from that, the given practices and assignments involving web resulted in the high learning result. Aside from that, the research result from Kurniawan (2017) found who mentioned that web-based learning increases motivation and the learning result of the students, especially in temperature and heat.

Environmental problems due to a lack of human awareness necessitate the early introduction of eco-literacy (Muthukrishnan, 2019). Then, the existence of web-based module learning media can be used as an effort to deal with environmental problems by placing it into learning. The effectiveness of the web-based science module that was previously developed showed a significant effect on students' problem solving (Miswami \& Nurcahyo, 2020), thinking skills (Putri \& Aznam, 2020), and activities (Astuti et al., 2020) improvements. In contrast to the previous science web-based module, the current module included the eco-literacy indicators and added supporting links. The module could be accessed in the pdf format or e-module that consisted of materials, questions, and video links related to the taught material. The addition of a web link was expected to offer broader and more exciting learning. The module could be accessed through the internet. As such, it can be used in various conditions and enable the students to learn independently. The objective of this research was to describe the feasibility (validity and effectiveness) of the developed web-based science learning module in improving students' understanding of ecoliteracy. The module was expected to enhance the understanding and attitude of the students towards the environment. Aside from that, this research can be the reference of the future researcher in conducting research or development of eco-literacy.

\section{METHOD}

This research methodology followed the 4D development model of Define, Design, Develop, and Disseminate proposed earlier (Thiagarajan et al., 1974). The module development was conducted from August 2020 to January 2021 in Science Education Major in FPIP of University of Muhammadiyah Sidoarjo. The developed module was first validated by internal and an external validator. The validation was conducted using a validation questioning sheet, which reviews the module's feasibility consisting of the content feasibility, language, presentation, component completeness, and physical form on a scale of 1-5. The average scores given by the validator were categorized based on the criteria listed in Table 1.

Table 1. Categorization Criteria of Module Validation Scoring (Ratumanan \& Laurens, 2011)

\begin{tabular}{ccc}
\hline Category & Description & Interval \\
\hline Very Valid & It can be used without revision & $3.6 \leq \mathrm{P} \leq 4$ \\
Valid & It can be used with minor revision & $2.6 \leq \mathrm{P} \leq 3.5$ \\
Less Valid & It can be used with a lot of revision & $1.6 \leq \mathrm{P} 2.5$ \\
\hline
\end{tabular}




\begin{tabular}{ccc}
\hline Category & Description & Interval \\
\hline Not Valid & $\begin{array}{c}\text { It cannot be used yet and still need } \\
\text { consultation }\end{array}$ & $\leq \mathrm{P} \leq 1.5$ \\
\hline
\end{tabular}

The module validity scoring was evaluated to know the stability and consistency of the developed module by using the formula below.

$$
\text { Percentage of Agreement }=\left(1-\frac{A-B}{A+B}\right) \times 100 \%
$$

where A denotes high score and B denotes low score. If the result of the module scoring instrument is 75\%, it is deemed reliable (Borich, 2016).

The module that had been validated and reliable would then be trialed on a limited basis by trial with one group pretest-posttest design on ten students of Grade VII. The trial consisted of two tests: before and after treatment. The pattern of research with one group pretest-posttest design was as follows:

$$
\mathrm{O}_{1} \mathrm{XO}_{2}
$$

With $\mathrm{O}_{1}$ is the test before treatment, $\mathrm{X}$ is the treatment which is the eco-literacy module and $\mathrm{O}_{2}$ is the second test after using eco-literacy module. The trial result data were analyzed using N-Gain (Borich, 2016) formula to know the result of eco-literacy understanding on students.

$$
N-\text { Gain }=\frac{\text { posttest score }- \text { pretest score }}{\text { maximum score }- \text { pretest score }}
$$

where $\mathrm{X}$ denotes treatment, N-Gain is maximum gain, Pretest is the initial score of learning, and Posttest is the final score of learning.

The test results were calculated using the n-gain formula, then analyzed using the n-gain score criteria (Borich, 2016), as shown in Table 2.

Table 2. N-gain score criteria

\begin{tabular}{ccc}
\hline No & Score $<\mathrm{g}>$ & Criteria \\
\hline 1 & $<\mathrm{g}>\geq 0.7$ & High \\
2 & $0.7><\mathrm{g}>\geq 0.3$ & Enough \\
3 & $<\mathrm{g}><0.3$ & Less \\
\hline
\end{tabular}

\section{RESULT AND DISCUSSION}

The define stage was carried out by analyzing some basic competencies to determine the appropriate science material in designing and manufacturing tools later. The analysis was carried out to define students and material needs (Gorbi Irawan et al., 2018). The basic competencies chosen in this research were as follow:

- Sub-section 3.4: Define the concept of temperature, expansion, heat, heat transfer, and the implementation in daily life, including the mechanism to maintain the stability of body temperature in humans and animals

- Sub-section 4.4: Conduct an experiment to examine the influence of heat on temperature and the form of things and the heat transfer.

The chosen basic competence then combined with four eco-literacy indications: awareness of environment condition, interest in environment condition, considering 
the an environmental condition for them, and trying to do recovery actions on environment condition (Nadiroh et al., 2019).

In the design stage, the designing of module tools was conducted with the initial stage of learning syllabus creation based on the basic competence in the previous stage. After that, the module arrangement was conducted. Module arrangement started by deciding the module cover, content design, and book content arrangement. The module cover is dominated in white as background and blue line as its complement. The cover also contains a picture of what is happening on earth. This picture was chosen to match the module title, which was "Eco-literacy Module" as shown in Figure 1.

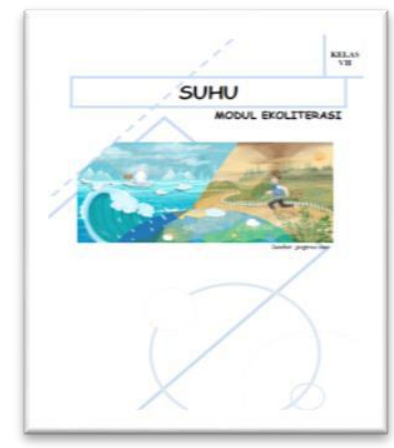

Figure 1. Module Cover

The module arranged to learn one basic competence, which developed into six meetings with a total face-to-face of 15 hours of learning. The eco-literacy module consists of 5 learning chapters covering temperature, expansion of solids, expansion of liquids and gas, change of temperature and ecosystem, and the cause and ways to prevent the change of environmental temperature integrated with the eco-literacy indicators. Every chapter contains materials and competence tests. Material given is in the form of the text of information summary equipped with pictures related to the material. Aside from that, sections of "Do You Know?" contain additional info regarding real events in daily life related to the taught material. Aside from material, the module was also equipped with a competence test. There are 6 competence tests arranged. Competence test is in the form of questions and observing activities that have to be done by the students. There are video links related to the material inserted, Do You Know, or the background in the competence test, as shown in Figures 2 and 3. These links are an upgrade from the module created aside from eco-literacy on chosen basic competence. The module was compiled in a PDF (Portable Document Format) document easily accessed and connected to the internet, so the video links inserted can be accessed (Figure 4).

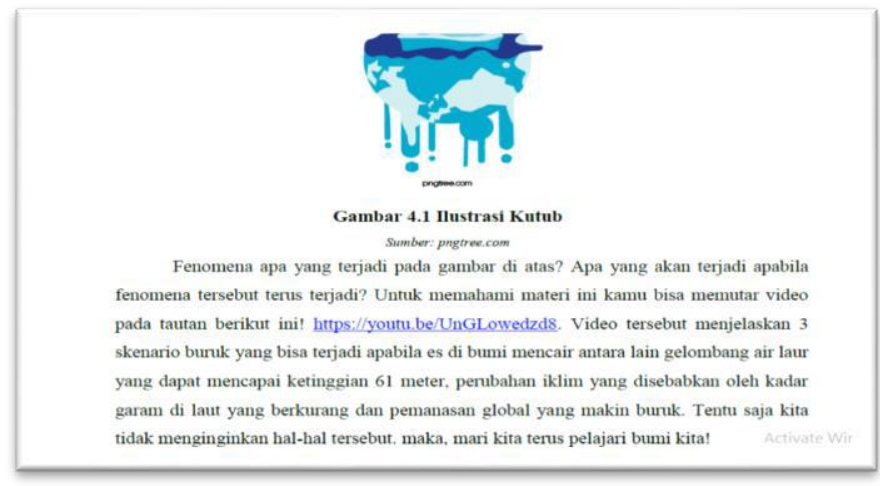

Figure 2. Video Links on Material 


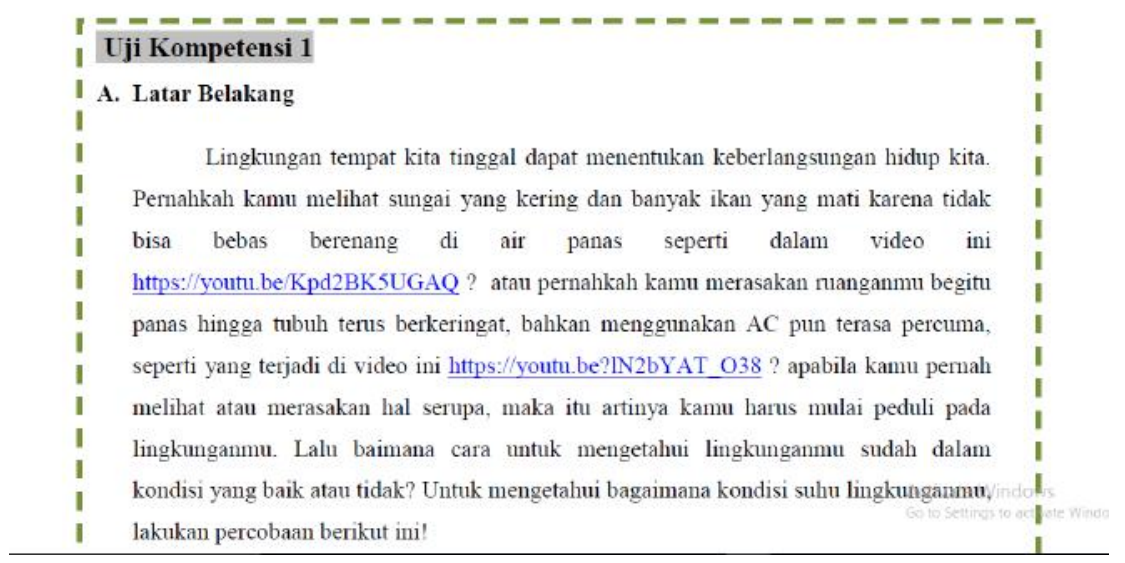

Figure 3. Video Links on Competency Test

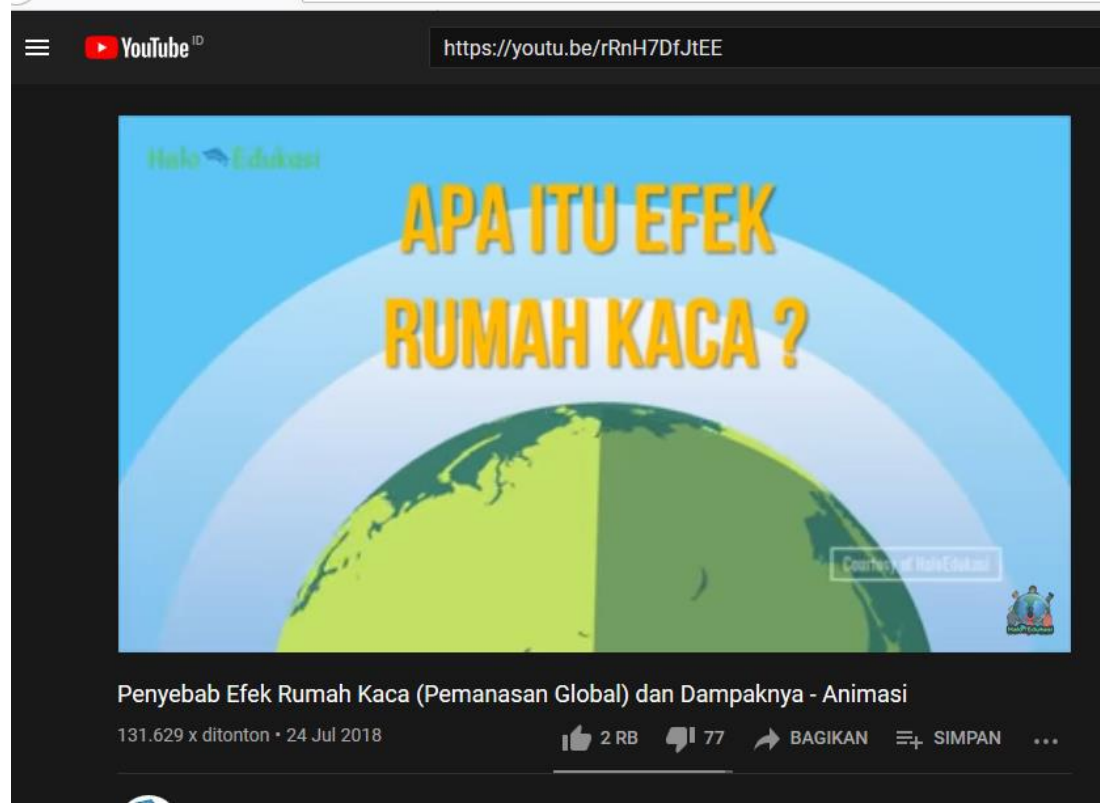

Figure 4. Video from Link

At the development stage, the module then go through a validation process to determine the validity and reliability. According to Almanasreh et al. (2019), validation was carried out to provide evidence of how much the instrument is appropriate and relevant for an assessment purpose. Reliability refers to measurements that provide consistent results and the same value (Mohajan, 2017). Two experts from external campuses carried the validation process, namely science practitioners at MTs 1 Jombang and campus internal lecturers. Module validation was done by using a validation questionnaire sheet. The validation questionnaire sheet contains the assessment criteria for the entire content of the module. There are five criteria in the validation questionnaire, including the feasibility of content, language, presentation, completeness of components, and physical form. This assessment criterion was supported by Munthe et al. (2019), which states that a feasibility analysis of content, language, presentation, and physical graphics can be used to determine the feasibility level of the developed module. This feasibility is characterized by high validity and reliability results so that the module can be used in a study (Dwianto et al., 2017). The following are the assessment criteria in the validation questionnaire, as shown in Table 3. 
Table 3. Module Assessment Criteria

\begin{tabular}{|c|c|c|}
\hline No & Criteria & Sub-criteria \\
\hline \multirow{8}{*}{1} & \multirow{6}{*}{ Content Feasibility } & a. Suitability with the SC and BC \\
\hline & & b. Suitability with the need of the students \\
\hline & & c. Suitability with the taught material needs \\
\hline & & d. Suitability with the eco-literacy indicators \\
\hline & & e. Beneficial to expand knowledge insights \\
\hline & & f. Related with the daily life \\
\hline & \multirow{5}{*}{ Language } & a. Communicative varieties of language \\
\hline & & b. The simple and straightforward sentences \\
\hline \multirow[t]{3}{*}{2} & & c. Effective and efficient use of language \\
\hline & & d. Suitability with the Bahasa Indonesia principle \\
\hline & & e. Clearness of information \\
\hline \multirow{4}{*}{3} & \multirow{4}{*}{ Presentation } & a. Clearness of objectives \\
\hline & & b. Presentation description \\
\hline & & c. Interactivities (stimulations and responses) \\
\hline & & d. Completeness of information \\
\hline 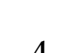 & Component & a. There is the material description \\
\hline 4 & Completeness & $\mathrm{b}$. There is practice \\
\hline 5 & Physical Form & a. Interesting presentation and packaging \\
\hline
\end{tabular}

The validation results of the two experts can be seen in Table 4 .

Table 4. Validation and reliability of module developed

\begin{tabular}{|c|c|c|c|c|c|c|}
\hline \multirow[b]{2}{*}{ No } & \multirow{2}{*}{$\begin{array}{c}\text { Assessment } \\
\text { Aspect }\end{array}$} & \multicolumn{2}{|c|}{ Validator } & \multirow[b]{2}{*}{ Average } & \multirow[b]{2}{*}{ Description } & \multirow[b]{2}{*}{ Reliability } \\
\hline & & 1 & 2 & & & \\
\hline 1 & $\begin{array}{l}\text { Content } \\
\text { Feasibility }\end{array}$ & 3.2 & 4.2 & 3.7 & Very Valid & \\
\hline 2 & Language & 3.8 & 3.6 & 3.7 & Very Valid & \\
\hline 3 & Presentation & 4 & 3.8 & 3.9 & Very Valid & 0.83 \\
\hline 4 & $\begin{array}{l}\text { Component } \\
\text { Completeness }\end{array}$ & 3 & 4 & 3.5 & Valid & \\
\hline 5 & Physical Form & 3 & 4 & 3.5 & Valid & \\
\hline
\end{tabular}

Based on the validation result from the two experts in Table 4, the module has a score of 3.66, which falls into the Valid category. The score of 3.66 was obtained from the average calculation of 5 module assessment criteria: content feasibility, language, presentation, component completeness, and physical form. This result is in accordance with the opinion which states that the development of a good module must include a good appearance and content (Misbah et al., 2020). The higher the validation number of teaching material, the higher it's meaning and function (Hartini et al., 2018). Therefore, the validation result of 3.66 and the reliability calculation of 0.83 imply that the module is considered valid and reliable. This conclusion is also supported by Lim and Poo (2021) which stated that a reliability result of more than 0.7 is considered good, so it can be used with slight corrections according to the advice given by experts. Table 5 lists some suggestions and corrections from the validators.

Table 5. Advice and Correction of Learning Module

\begin{tabular}{lll}
\hline No & \multicolumn{1}{c}{ Advice } & \multicolumn{1}{c}{ Correction } \\
\hline 1 & $\begin{array}{l}\text { There are several uses of too long } \\
\text { sentences }\end{array}$ & $\begin{array}{l}\text { Change the sentences to be more } \\
\text { straightforward }\end{array}$ \\
\hline
\end{tabular}




\begin{tabular}{lll}
\hline No & \multicolumn{1}{c}{ Advice } & \multicolumn{1}{c}{ Correction } \\
\hline 2 & $\begin{array}{l}\text { There are uses of language which less } \\
\text { effective and efficient }\end{array}$ & $\begin{array}{l}\text { Change the use of language in several } \\
\text { sentenced to be more effective and } \\
\text { efficient } \\
\text { Change the language in certain sentences } \\
\text { to be more communicative }\end{array}$ \\
\hline
\end{tabular}

Based on the advice given by the experts, the use of appropriate sentences and language is one of the critical factors so that the students can easily understand the material given. Using language that fits the good and right principles can convey the message effectively and efficiently and clarify information (Lestari et al., 2019). Another piece of advice given by the expert is increasing communicative language use. Communicative language in module creation can help students understand easier and practice independent study (Wahyuni \& Puspari, 2017).

After the validation process and completing some improvements based on suggestions from experts, the next stage of development is testing - the trial conducted in a limited trial to 10 students. If the number of students is less than 10, the information insufficiently describes the population. If more than 20, the information obtained can be exaggerated and less valuable (Wahyuni \& Puspari, 2017). This statement shows that this limited trial can be done to 10 students. The trial is conducted by one group pretest-posttest trial design to know the quality and effectiveness of the developed module (Pamungkas et al., 2017). The students were given the pretest to know the initial eco-literacy understanding. The materials were taught to the students using the eco-literacy module media, and the posttest will be held after the use of the module. The summary result of the average pretest and posttest scores can be seen in Table 6 .

Table 6. Average of Pretest Posttest

\begin{tabular}{lll}
\hline & Pretest & Posttest \\
\hline Total & 437 & 834.975 \\
\hline Average & 43.7 & 83,49 \\
\hline
\end{tabular}

Then, the score data will be analyzed to know the enhancement of the ecoliteracy understanding after using the N-gain test and categorizing based on Table 2 to determine the module's effectiveness. The result of the $\mathrm{N}$-gain test calculation can be seen in Table 7.

Table 7. N-Gain Calculation Result

\begin{tabular}{lllll}
\hline Component & Pretest & Posttest & N-gain & Criteria \\
\hline Average & 43.7 & 83.49 & & \\
Max Score & 54.75 & 88 & 0.703 & High \\
Min Score & 36.25 & 76.5 & & \\
\hline
\end{tabular}

Based on the result of the analysis of web-based module effectiveness in increasing the eco-literacy result, it is obtained that the average scores of pretest, posttest, and $\mathrm{N}$-gain are 43.783 .49 and 0.703 . The $\mathrm{N}$-gain score of 0.703 shows that the eco-literacy understanding enhancement in 10 students who took part in the trial is deemed high. The findings are in line with Ma (2019) where a significant change in the pretest and posttest was obtained. Thus, the web-based module is deemed effective in enhancing eco-literacy understanding. 
Several studies have implemented and developed web-based science modules to improve students' learning outcomes. Putri and Aznam (2020) implemented a webbased science module with guided inquiry to improve students' thinking skills found that experimental group thinking skills taught using web-based science with guided inquiry increased more effectively than the control group. Furthermore, Miswami and Nurcahyo (2020), which developed a science web module integrated with tannery waste, stated that students' problem-solving skills improved after using web-based modules developed. On the other hand, Zahroh (2020) found that web-based thematic modules developed did not significantly impact students' learning outcomes and digital literacy skills. In contrast, the current study focused on a web-based science learning module integrated with eco-literacy to improve students' understanding of eco-literacy that claimed to be very important to be taught (Ikhsan et al., 2019; Sigit et al., 2021; Williams, 2017; Yannis \& Gillian, 2017) to reduce the lack of sufficient knowledge in preserving the environment (Nadiroh et al., 2019).

\section{CONCLUSION}

Based on the result of the research, it can be concluded that the developed Science learning module is deemed valid, reliable, and effective to enhance the ecoliteracy understanding of the students. This research was unfortunately limited only to trials in the small class. It needs to be conducted on a larger scale for more convincing results.

\section{ACKNOWLEDGEMENT}

Thank you to the Ministry of Education and Culture of Indonesia that has funded the research (Decree Number: 1686/E2/TU/2020).

\section{REFERENCES}

Almanasreh, E., Moles, R., \& Chen, T. F. (2019). Evaluation of methods used for estimating content validity. Research in Social and Administrative Pharmacy, 15(2), 214-221. https:/ / doi.org/10.1016/j.sapharm.2018.03.066

Asi, N. B., \& Anggraeni, M. E. (2018). Pengaruh Metode Pemberian Tugas Dan Latihan Soal Termokimia Menggunakan Aplikasi Berbasis WWW Di Program Studi Pendidikan Biologi JPMIPA FKIP UPR. Prosiding Seminar Nasional Pendidikan Kimia, 108-116.

Astuti, L., Wihardi, Y., \& Rochintaniawati, D. (2020). The Development of Web-Based Learning using Interactive Media for Science Learning on Levers in Human Body Topic. Journal of Science Learning, 3(2), 89-98. https:// doi.org/10.17509/jsl.v3i2.19366

Borich, G. D. (2016). Observation Skills for Effective Teaching: Research-Based Practice (0 ed.). Routledge. https:/ / doi.org/10.4324/9781315633206

Desfandi, M., Maryani, E., \& Disman, D. (2017). Building Ecoliteracy Through Adiwiyata Program (Study at Adiwiyata School in Banda Aceh). Indonesian Journal of Geography, 49(1), 51. https:/ / doi.org/10.22146/ijg.11230

Dwianto, A., Wilujeng, I., Prasetyo, Z. K., \& Suryadarma, I. G. P. (2017). The Development of Science Domain Based Learning Media Which is Integrated with Local Potention to Improve Science Process Skill and Scientific Attitude. Jurnal Pendidikan IPA Indonesia, 6(1). https:/ / doi.org/10.15294/jpii.v6i1.7205 
El-Mallah, R. K. E.-D., Aref, A. A. el H., \& Sherif, S. (2019). The role of social responsibility in protecting the environment - a case of the petrochemical companies in Alexandria Governorate. Review of Economics and Political Science, 1-33. https:// doi.org/10.1108/REPS-04-2019-0052

Fatah, A. H., Asi, N. B., Anggraeni, M. E., Wulandari, A., \& Latif, A. (2021). Pengembangan Media Pembelajaran Kimia Dasar Berbasis Web Pada Pokok Bahasan Termokimia. Jurnal Ilmiah Kanderang Tingang, 12(1), 56-64. https:// doi.org/10.37304/jikt.v12i1.122

Fathiyati, R., \& Utami, R. P. (2016). Pengembangan Media Pembelajaran Biologi Berbasis Macromedia Flash sebagai Sumber Belajar Bagi Siswa SMA/MA Kelas XI Semester 2 Materi Pokok SIstem Reproduksi Manusia. Seminar Nasional IX Pendidikan Biologi FKIP UNS, 211-217.

Gorbi Irawan, A., nyoman Padmadewi, N., \& Putu Artini, L. (2018). Instructional materials development through 4D model. SHS Web of Conferences, 42, 00086. https:// doi.org/10.1051/shsconf/20184200086

Haris, A. M., \& Purnomo, E. P. (2016). Implementasi CSR (Corporate Social Responsibility) PT. Agung Perdana Dalam Mengurangi Dampak Kerusakan Lingkungan. Journal of Governance and Public Policy, 3(2), 203-225. https:// doi.org/10.18196/jgpp.v3i2.2627

Hartini, S., Firdausi, S., Misbah, M., \& Sulaeman, N. F. (2018). The Development of Physics Teaching Materials Based on Local Wisdom to Train Saraba Kawa Character. Jurnal Pendidikan IPA Indonesia, 7(2), 130-137. https:// doi.org/10.15294/jpii.v7i2.14249

Ikhsan, F. A., Kurnianto, F. A., Apriyanto, B., \& Nurdin, E. A. (2019). The Effectivity of Environmental Education in Scaffolding Students' Ecological Literacy. Jurnal Pendidikan IPA Indonesia, 8(3). https:/ / doi.org/10.15294/jpii.v8i3.14522

Iswari, R. D., \& Utomo, S. W. (2017). Evaluasi Penerapan Program Adiwiyata Untuk Membentuk Perilaku Peduli Lingkungan di Kalangan Siswa (Kasus: SMA Negeri 9 Tangerang Selatan dan MA Negeri 1 Serpong). Jurnal Ilmu Lingkungan, 15(1), 35. https:/ / doi.org/10.14710/jil.15.1.35-41

Itafarida, S., Herupradoto, E. B. A., Rosyidah, U. N. D., \& Rusnaningtias, E. (2019). Family-based collaborative eco-literacy model for sustainable city. Masyarakat, $\begin{array}{llll}\text { Kebudayaan Dan } & \text { Politik, }\end{array}$ https:/ / doi.org/10.20473/mkp.V32I22019.168-178

Kukkonen, J., Kärkkäinen, S., \& Keinonen, T. (2018). Examining the Relationships between Factors Influencing Environmental Behaviour among University Students. Sustainability, 10(11), 4294. https:/ / doi.org/10.3390/su10114294

Kurniawan, F. A. (2017). Pengaruh pembelajaran berbasis web terhadap motivasi dan hasil belajar siswa kelas x SMA Negeri paguyangan pada mata pelajaran fisika pokok bahasan suhu dan kalor. Scientiae Educatia, 6(1), 1. https:/ / doi.org/10.24235/sc.educatia.v6i1.1279

Lestari, R. A., Hardeli, Dewata, I., \& Ellizar, E. (2019). Validity and practicality of buffer solution module based on discovery learning with a scientific approach to increase the critical thinking ability of 11 th grade high school students. Journal of Physics: Conference Series, 1185, 012150. https:// doi.org/10.1088/1742-6596/1185/1/012150 
Lim, H. L., \& Poo, Y. P. (2021). Diagnostic Test to Assess Misconceptions on Photosynthesis and Plant Respiration: Is It Valid and Reliable? Jurnal Pendidikan IPA Indonesia, 10(2), 241-252. https:/ / doi.org/10.15294/jpii.v10i2.26944

Ma, C. M. S., Shek, D. T. L., \& Chen, J. M. T. (2019). Changes in the Participants in a Community-Based Positive Youth Development Program in Hong Kong: Objective Outcome Evaluation Using a One-Group Pretest-Posttest Design. Applied Research in Quality of Life, 14(4), 961-979. https:// doi.org/10.1007/s11482-018-9632-1

Mardliyah, W., Sunardi, S., \& Agung, L. (2018). Peran Manusia Sebagai Khalifah Allah di Muka Bumi: Perspektif Ekologis dalam Ajaran Islam. Jurnal Penelitian, 12(2), 355-378. https:/ / doi.org/10.21043/jp.v12i2.3523

McBride, B. B., Brewer, C. A., Berkowitz, A. R., \& Borrie, W. T. (2013). Environmental literacy, ecological literacy, ecoliteracy: What do we mean and how did we get here? Ecosphere, 4(5), 1-20. https:// doi.org/10.1890/ES13-00075.1

McCarthy, G., \& Burke, T. A. (2017). We Need a Strong Environmental Protection Agency: It's About Public Health! American Journal of Public Health, 107(5), 649651. https:/ / doi.org/10.2105/ AJPH.2017.303728

Misbah, M., Hirani, M., Annur, S., Sulaeman, N. F., \& Ibrahim, M. A. (2020). The Development and Validation of a Local Wisdom-Integrated Physics Module to Grow the Students' Character of Sanggup Bagawi Gasan Masyarakat. JIPF (Jurnal Ilmu Pendidikan Fisika), 5(1), 1-7. https:/ / doi.org/10.26737/jipf.v5i1.1280

Miswami, A. I., \& Nurcahyo, H. (2020). Science Web-Module Integrated with Tannery Waste as Local Potential to Improve Studentsâ€TM Problem Solving. Biosaintifika: Journal of Biology \& Biology Education, 12(3), 392-398. https:/ / doi.org/10.15294/biosaintifika.v12i3.24356

Mohajan, H. K. (2017). Two criteria for good measurements in research: Validity and reliability. Annals of Spiru Haret University. Economic Series, 17(4), 59-82. https://doi.org/10.26458/1746

Munthe, E. A., Silaban, S., \& Muchtar, Z. (2019). Discovery Learning Based E-Module on Protein Material Development. 710-713. https://www.atlantispress.com/ proceedings/aisteel-19/125928461

Muthukrishnan, R. (2019). Using Picture Books to Enhance Ecoliteracy of First-Grade Students. International Journal of Early Childhood Environmental Education, 6(2), 19-41.

Nadiroh, N., Hasanah, U., \& Zulfa, V. (2019). Behavioral Geography: An Ecoliteracy Perspective and Critical Thinking Skills in Men and Women. Indonesian Journal of Geography, 51(2), 114. https:/ / doi.org/10.22146/ijg.36784

Nurfajriani, N., Azrai, E. P., \& Sigit, D. V. (2018). Hubungan ecoliteracy dengan perilaku pro-lingkungan peserta didik SMP. Florea: Jurnal Biologi Dan Pembelajarannya, 5(2), 63. https:/ / doi.org/10.25273/florea.v5i2.3126

Pamungkas, Z. S., Wahyuni, S., \& Prihandono, T. (2017). Kelayakan Modul Pembelajaran IPA Berbasis Potensi Lokal Pada Pokok Bahasan Perubahan Benda Di SMPN 1 Semboro Kabupaten Jember. JURNAL PEMBELAJARAN FISIKA, 6(3), 270-278. https:// doi.org/10.19184/jpf.v6i3.5323

Putri, A. S., \& Aznam, N. (2020). Web modul ipa berbasis inkuiri terbimbing untuk meningkatkan thinking skill. EDUSAINS, 12(1), 47-53. https:// doi.org/10.15408/es.v12i1.11034 
Ratumanan, T. G., \& Laurens, T. (2011). Penilaian Hasil Belajar pada Tingkat Satuan Pendidikan. Unesa University Press.

Rusmawan. (2017). Ecoliteracy dalam konteks pendidikan IPS. SOSIO-DIDAKTIKA: Social Science Education Journal, 4(2), 39-50.

Sigit, D. V., Azrai, E. P., Heryanti, E., Ichsan, I. Z., Jajomi, Y. P., \& Fadrikal, R. (2019). Development Green Consumerism E-Book for Undergraduate Students (GCEBUS) as Learning Media in Environmental Learning. Indian Journal of Public Health Research E Development, 10(8), 2026-2031. https:// doi.org/10.5958/0976-5506.2019.02152.1

Sigit, D. V., Prastiwi, L., Ristanto, R. H., \& Rifan, M. (2021). Adiwiyata school in Indonesia: A correlation between eco-literacy, environmental awareness, and academic ability with environmental problem-solving skill. Journal of Physics: Conference Series, 1796(1), 012068. https://doi.org/10.1088/17426596/1796/1/012068

Siregar, M., Meilanie, S. M., \& Purwanto, A. (2020). Pengenalan Ecoliteracy pada Anak Usia Dini melalui Metode Bercerita. Jurnal Obsesi : Jurnal Pendidikan Anak Usia Dini, 5(1), 719-728.

Solikin, I. (2018). Implementasi E-Modul pada Program Studi Manajemen Informatika Universitas Bina Darma Berbasis Web Mobile. Jurnal RESTI (Rekayasa Sistem Dan Teknologi Informasi), 2(2), 492-497.

Solikin, I., \& Amalia, R. (2019). Materi digital berbasis web mobile menggunakan model 4d. SISTEMASI, 8(3), 321. https:/ / doi.org/10.32520/stmsi.v8i3.461

Supriatna, N. (2016). Ekopedagogi. Remaja Roesdakarya.

Syukron, A. (2019). Ekoliterasi: Desain pembelajaran bahasa indonesia berwawasan lingkungan. FKIP E-PROCEEDING, 61-70.

Thiagarajan, S., Semmel, D., S., \& Semmel, M., I. (1974). Instructional Development for Training Teachers of Exceptional Children. Indiana University Bloomington.

Wahyudi, T. N., Prasetyo, D., Prasetyo, A. D., Rinawati, R., Kusumawati, I., Hasana, U. U., Ashari, F. A., Aisyah, D. R., Anggraini, R., \& Gistiani, T. L. (2020). Penanaman Karakter Sadar Lingkungan Melalui Program Adiwiyata di MIM Potronayan 2 Boyolali. Buletin KKN Pendidikan, 2(1). https:/ / doi.org/10.23917/bkkndik.v2i1.10794

Wahyuni, H. I., \& Puspari, D. (2017). Pengembangan Modul Pembelajaran Berbasis Kurikulum 2013 Kompetensi Dasar Mengemukakan Daftar Urut Kepangkatan dan Mengemukakan Peraturan Cuti. JPEKA: Jurnal Pendidikan Ekonomi, Manajemen Dan Keuangan, 1(1), 54-68. https:/ / doi.org/10.26740/jpeka.v1n1.p54-68

Williams, R. D. (2017). An Assessment of Environmental Literacy Among Oklahoma Public High School Students and the Factors Affecting Students' Environmental Literacy [Harvard Extension School]. https:/ / dash.harvard.edu/handle/1/33826276

Yannis, H., \& Gillian, J. (2017). Toward More Effective Storytelling for Raising Environmental Awareness in Young Students. Journal of Advances in Education Research, 2(1). https:/ / doi.org/10.22606/jaer.2017.21002

Zahroh, N. L. (2020). Web-based thematic module in social studies to improving student digital literation skills. Harmoni Sosial: Jurnal Pendidikan IPS, 7(1), 7884. https://doi.org/10.21831/hsjpi.v7i1.28250 